\title{
KARST IN GYPSUM AREA: CASE STUDY NEAR WIŚLICA (POLISH UPLANDS)
}

DOI: http://dx.doi.org/10.18509/GBP.2018.14

UDC: $551.435 .8: 549.766 .21(438)$

\author{
Tomasz Kalicki ${ }^{1}$ \\ Emanuela Malęga ${ }^{2}$ \\ Marcin Frączek ${ }^{1}$ \\ Pawel Przepióra ${ }^{1}$ \\ ${ }^{1}$ Jan Kochanowski University in Kielce, Institute of Geography, Department of \\ Geomorphology, Geoarchaeology and Environmental Management, Kielce, Poland, \\ ${ }^{2}$ Jan Kochanowski University in Kielce, Institute of Geography, Student Research Group of \\ Geomorphologists „Złoty Bażant”, Poland
}

\begin{abstract}
Wiślica, is located in the southern part of Nida Basin with karst phenomena developed on gypsum. On the anticline lines were formed inversion karst basins occupied by swamps and bogs. Within the flat valley bottom near Wiślica, 1-3 km wide, on one morphological level occur:

- plain on a karstic depression along the line of gypsum anticline with the Late Subboreal peat bog;

- the alluvial plain formed by the Nida river, probably with the several cut and fill alluvial bodies of different age representing to changes of river pattern during the Late Glacial and Holocene;

- gypsum dome.
\end{abstract}

Keywords: Nida Basin, Wiślica, gypsum karst, Nida river valley

\section{INTRODUCTION}

According to the division of Poland into the physical-geographical regions, land called Ponidzie lies on Polish Uplands province (34), the Małopolska Upland subprovince (342), the Nida Basin macroregion (342.2) and the Nida Valley (342.25) and Solecka Basin (342.26) mezoregions [1]. Study area is located in the southern part of Nida Basin between two elevations Wodzisław Horst and Pińczów Horst. This is part of Nida river valley near Wiślica. Nida river, $2^{\text {nd }}$ order tributary of the Vistula river, drained northcentral part of the Nida Basin and the southern part of the Holy Cross Mts. [2] (Fig. 1).

\section{GEOLOGY}

The Cretaceous marls are covered with the Miocene (Tortonian) rocks in the study area. In connection with the geological structure the research area is called "Nida gypsum", which is the largest outcrop of Miocene (Badenian) evaporates developed in the preCarpathian Depression [3]. They occur within the Miocene sea sediments, with which they underwent a major tectonic reconstruction later. They formed around 13.4-11.1 million years ago [3]. They are exposed in an elongated longitudinal area (30 by $15 \mathrm{~km}$ ) north of Nida, within the Solec and Połaniec Basins and the Pińczów Horst. Outcrops of the "Nida gypsum" are grouped between Szaniec and Kije (in the north) and in the triangle 
between Busko, Bogucice and Wiślica (in the south). In a large part of them they are built of marls, limestones and gypsum, which are covered with Quaternary deposits. Thickness of the Quaternary covers is small - on the uplands is typically a few meters, and in the valleys reaches several meters. In the Nida Valley identified the Pleistocene sediments (e.g. tills, fluvioglacial sands, loess) and the Holocene alluvium (silts, sands, gravels) and peats.

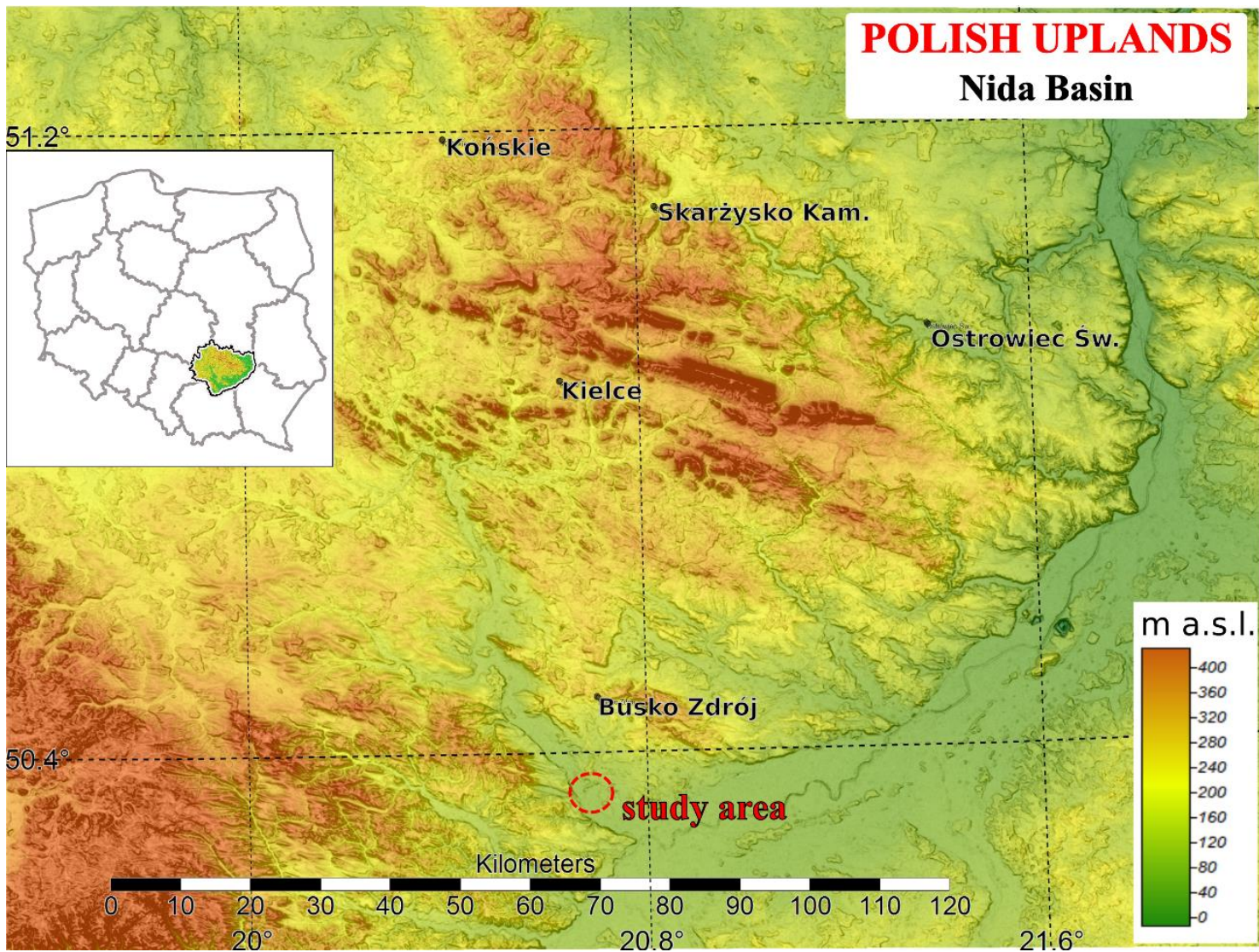

Figure 1. Location of the study area on Digital Elevation Model (DEM)

\section{RELIEF}

Pre-Quaternary relief of Ponidzie is closely related to the geological structure. Hills had a direction NNW-SSE and W-E. Also the direction of Nida river valley was determined by the tectonic system of the layers of the older substrate. The relief of Ponidzie is characterized by a very large variety. Particularly to deserve is the occurrence of a series of gypsum, thanks to which there were created unique in Poland wide variety of forms of gypsum karst [4].

The karst relief in the analyzed area is also closely related to the geological structure. Limestone, gypsum and marls succumb to karst processes here. Crusts lying on the surface and under the cover of other sediments undergo karst processes. In relief, the most important are those corresponding to an anticline and syncline of gypsum with karst phenomena and gypsum domes [3], [5]. On the anticline lines were formed inversion karst basins occupied by swamps and bogs lying directly on the Cretaceous marls. On the syncline lines formed sink holes, dry karst valleys (eg. Skorocice) [6]. 
Very distinct differentiation of present-day morphogenetic processes occur on western and eastern site of Nida river valley. On the western side morphogenesis of loess areas is conditioned primarily by lithology and land use. Loess are susceptible to the erosion, which results in the formation of a dense network of gorges even over $10 \mathrm{~m}$ deep. In the areas located on the eastern bank of the Nida River, steep slopes causes slope wash on arable fields, downhill creep, landslides, deflation in agricultural areas and fluvial processes in the bottoms of river valleys [4].

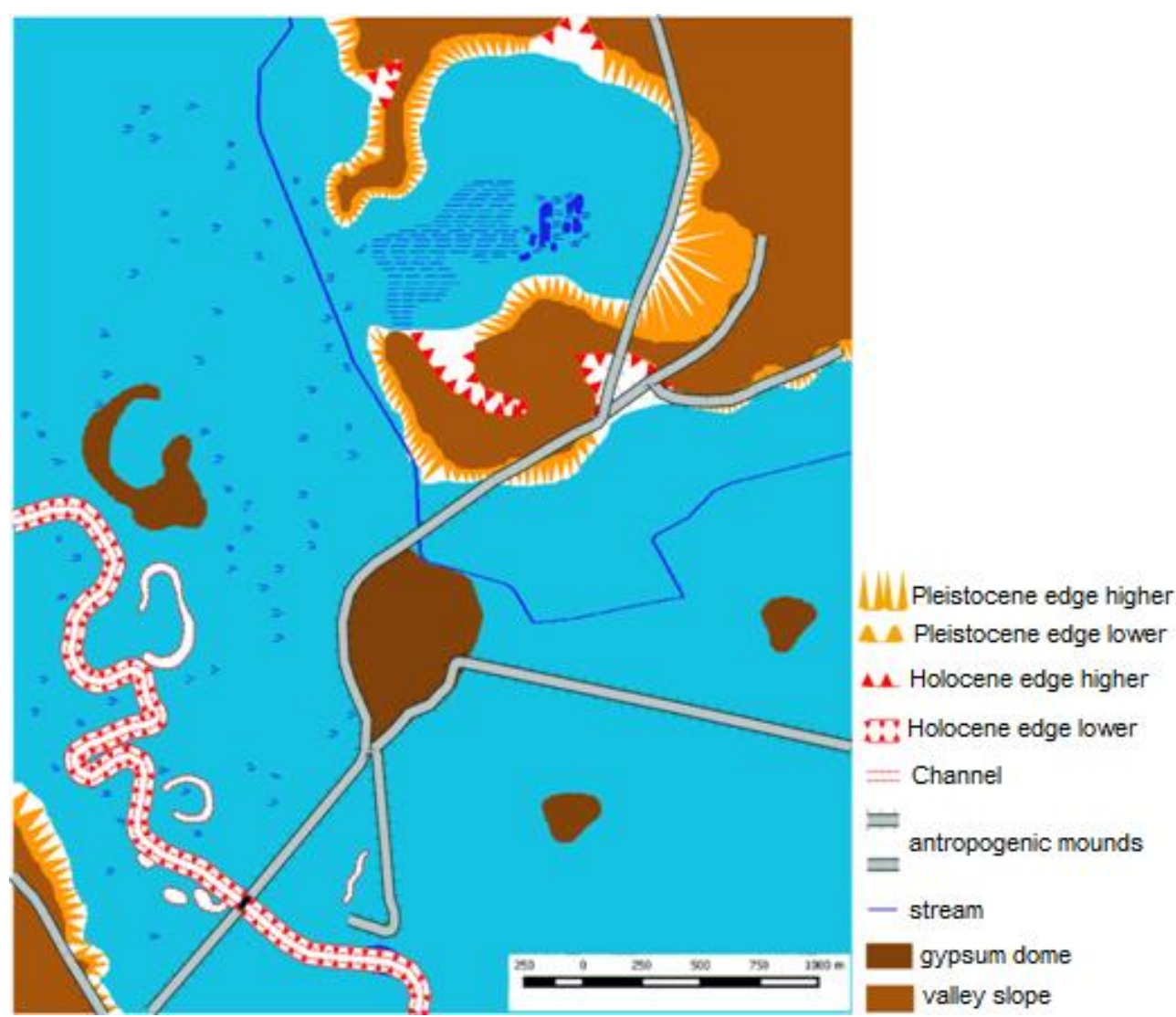

Figure 2. Geomorhological map of Nida river valley near Wiślica [2] 


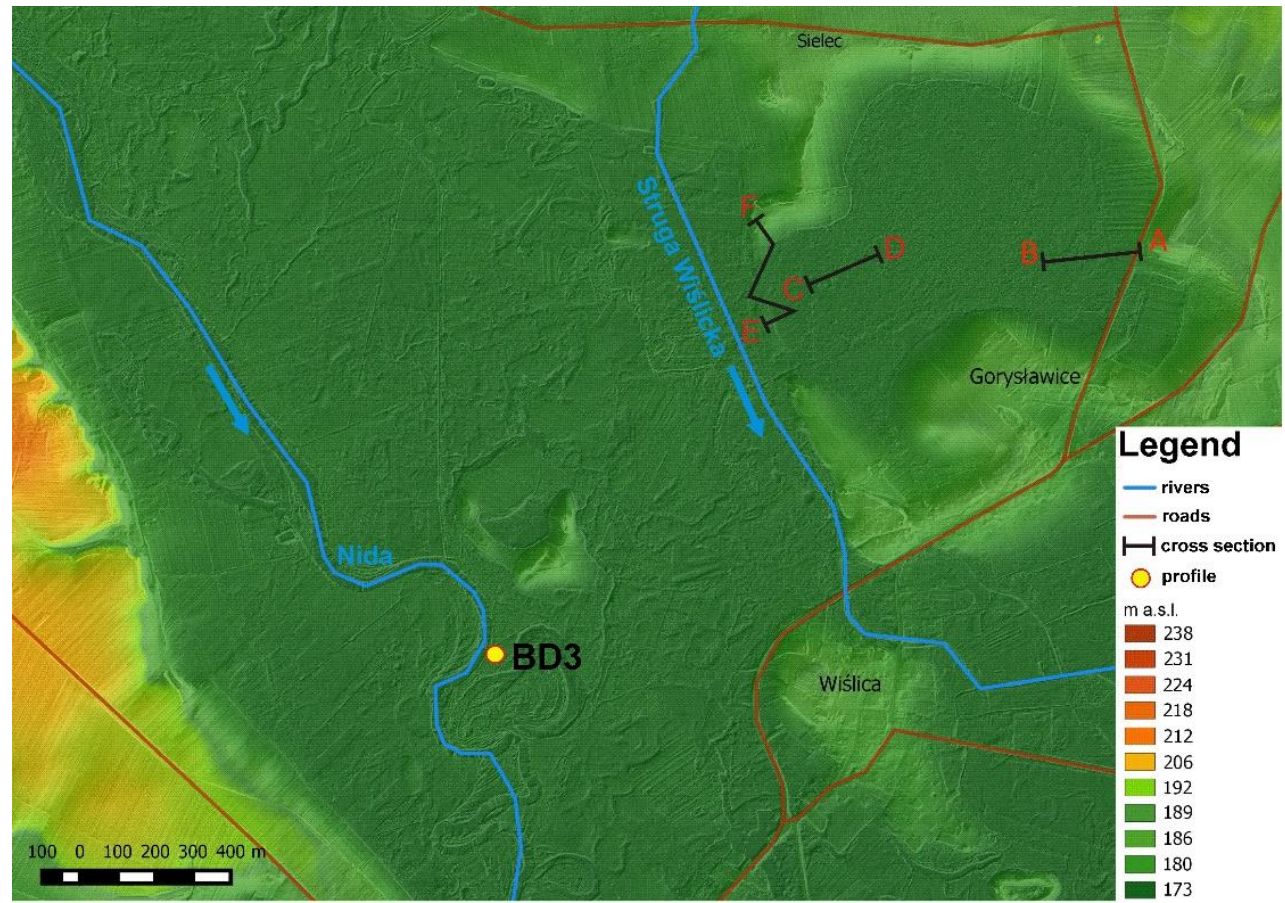

Figure 3. DEM of Nida valley near Wiślica with location of study cross section and profile

\section{RESULTS}

Detailed studied across of Nida river valley near Wiślica were done. Marls at Gorysławice and gypsum of the Wiślica anticline form the eastern limit of the subsequent Nida river valley in the study section. The western slope of the valley is rectilinear and steeper than the eastern one and covered with loess deposits. The flat valley bottom is up to 1-3 km wide. It is asymmetrical, with a wide and swampy left-side and narrow right-side (Fig. 2, $3)$.

Within the valley bottom on one morphological level occur:

- plain on a karst depression along the line of gypsum anticline [6]. The karst depression near Gorysławice (N of Wiślica) has a radius of about $300 \mathrm{~m}$ and with a "gap section" (about $400 \mathrm{~m}$ wide) connecting it to the south-west with the Nida river flood plain. Calcareous silts with malacofauna cover, locally also comprising with peaty silts (near the valley slope) and peats (far from the slope) occur in all boreholes. The thickness of organic sediments increases towards the central part of the depression and axis of the Nida river valley. The bottom of this stratum was radiocarbon dated at $4280 \pm 50$ ${ }^{14} \mathrm{C}$ yr BP (MKL-3131) 3027-2857 cal. yr BC (Fig. 4). This may indicate the presence of an episodic lake or pond with stagnant water here. From the Subboreal until the present day peat bog and swamp with small ponds ("water windows") occur. Traces of river flow were not found within the depression. Further borings are located in the western part of the karst depressions. In the CD cross-section below the organic sediments sandy silts with malacofauna were found. In the EF cross-section, situated on the edge of the karst depression and Nida floodplain, fine sands were found under a thin layer of organic sediments. Recent results from 2017 confirmed that we are dealing with a big form of karst. However, there are doubts whether this is a karst depression, or perhaps two separate big karst funnels. These forms have been combined in the Subboreal. 


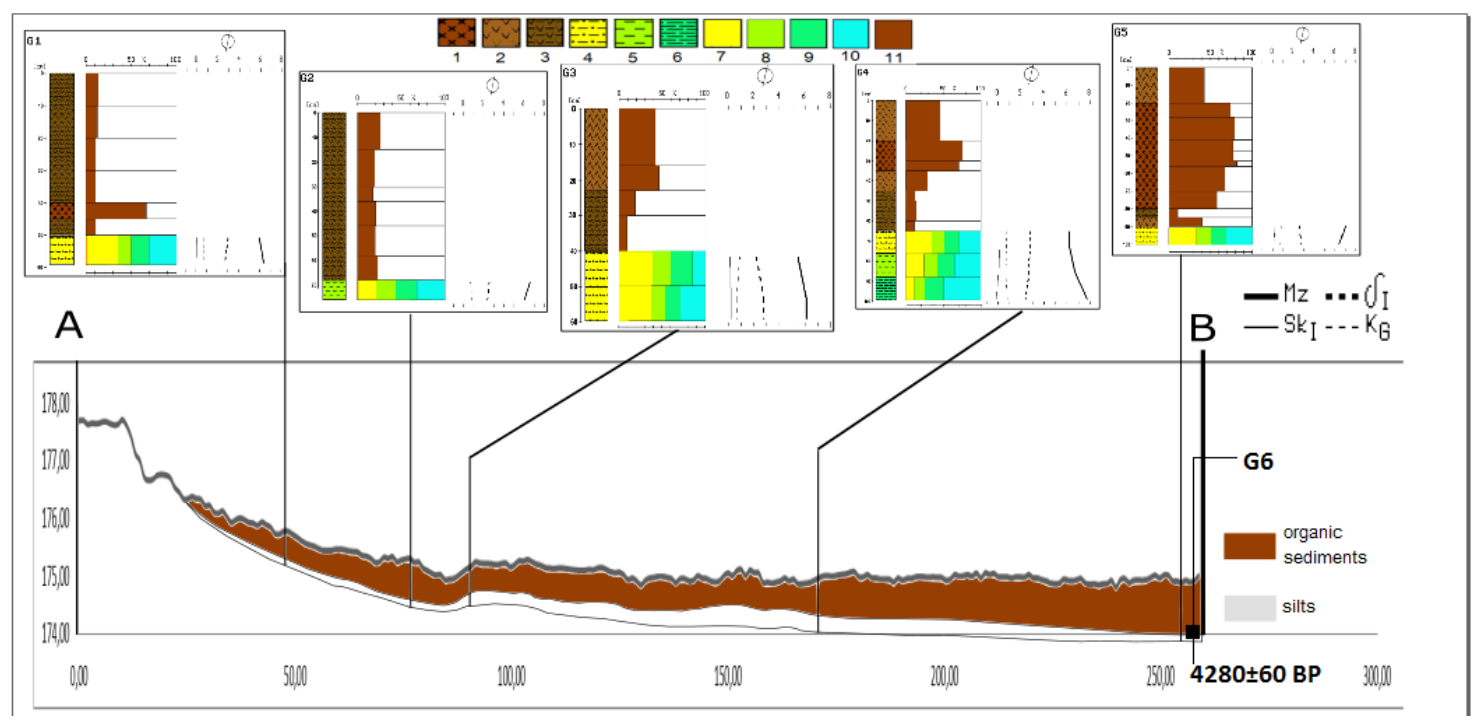

Figure 4. Geological section (A-B) across the karst depression. Location see Fig. 3.

Lithology: 1 -peats, 2 - clayey peats, 3 - peaty silts, 4 - sandy silts, 5 -silts, 6 - clayey silts; Fractions:

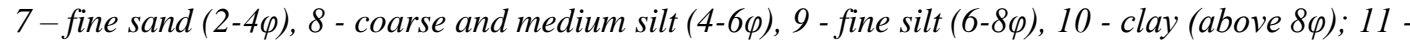
organic matter content; Folk-Ward's distribution parameters: $M z-$ mean diameter, $\delta_{I}-$ standard deviation (sorting), $S k_{I}-$ skewness, $K_{G}-$ kurtosis

- the alluvial plain formed by the Nida river, probably with the several cut and fill alluvial bodies of different age representing to changes of river pattern during the Late Glacial and Holocene. These bodies are evidenced by oxbow lakes preserved in the morphology. There are at least two generations: an older one, preserved in the form of straight stretching swamps, with a fairly straightforward course, that may suggest an anastomosing pattern of Nida river; and a younger one in the form of a palaeomeander preserved along the modern river bed. Alluvia are clearly facies differentiated. Three profiles were studied on an outcrop about $30 \mathrm{~m}$ long on the leftside of a flood plain located near the Babia Dupa gypsum dome. Organic sediments covered with overbank deposits occurred in BD 3 profile. The organic layers are probably palaeochannel fills, with buried soil in the top. According to radiocarbon dating, overbank deposition started about $1160 \pm 60{ }^{14} \mathrm{C}$ yr BP (MKL-3132) 763-994 cal. yr AD. Overbank alluvia have, generally, a fining upward sequence with two members which was accumulated in two phases of accretion (Fig. 5). It indicates that this accumulation could be connected with the meandering river (last stage of evolution of the Nida river). The presence of buried soil also indicates changes in fluvial activity and in rate of overbank accumulation in the last millennium 


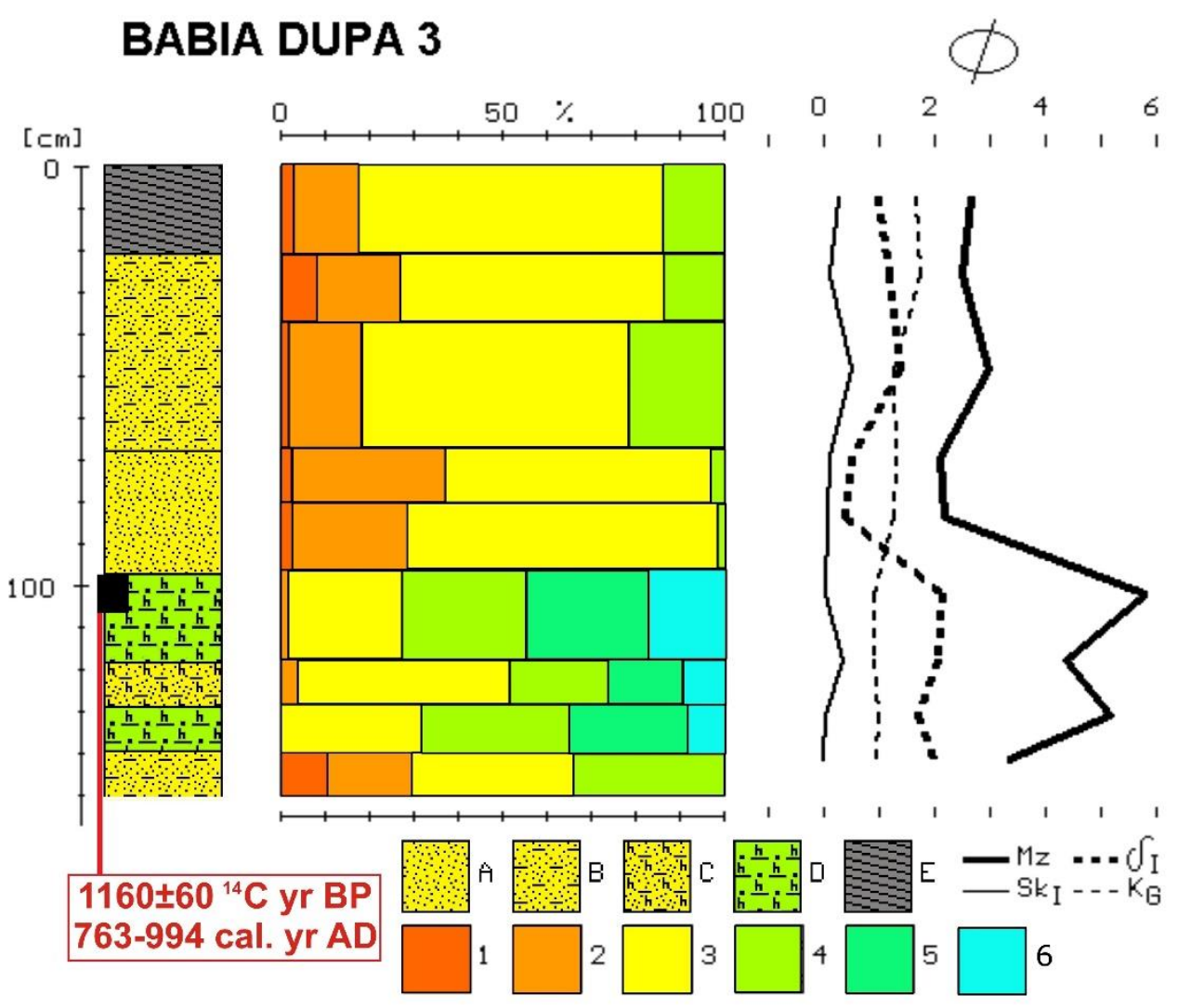

Figure 5. Lithology, grain size and Falk-Ward distribution parameters of Nida river sediments at Babia Dupa 3 (BD 3) profile near Wiślica

Lithology: 1 - sands, 2 - silty sands, 3 - sandy silts, 4 - soil, 5 - organic sediments; Fractions: 6 -

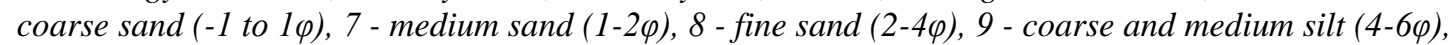

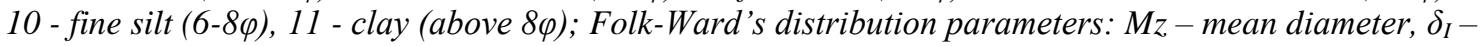
standard deviation (sorting), Sk $k_{I}-$ skewness, $K_{G}-$ kurtosis

- gypsum dome. Monoclinal gypsum elevations and gypsum tumuli create small overflood islands rising directly above the valley floor. These have been settled since the Neolithic [7]. On the dome at Wiślica a small fortified settlement was located at the turn of the $9^{\text {th }}$ and $10^{\text {th }} \mathrm{c}$. A.D. and, later, a stronghold in the $11^{\text {th }} \mathrm{c}$.

\section{CONCLUSSIONS}

Recent findings from the 2017 study confirmed the view that we are dealing with a karst depression consisting of two karst funnels separated by an elevation and now filled with clay mud. Both depression/congestion were compounded in the Subboreal.

\section{REFERENCES}

[1] Kondracki J., Geografia regionalna Polski, PWN, Warszawa, 2014.

[2] Malega E., Rzeźba i osady równiny zalewowej Nidy koło Wiślicy, Typescript of Bachelor's degree, Archives UJK, Kielce, 2016.

[3] Bąbel M., Geologia gipsów nadnidziańskich, IV Świętokrzyskie spotkania geologicznogeomorfologiczne nt. Regionalne aspekty funkcjonowania systemów dolinnych, „Jodłowy Dwór” 
pod Świętym Krzyżem, Akademia Świętokrzyska im. Jana Kochanowskiego, Kielce, pp. 11-12, 2006.

[4] Dłużewski M., Rojan E., Tsermegas I., Rzeźba Ponidzia, VII Świętokrzyskie spotkania geologiczno-geomorfologiczne nt. Georóżnorodność Ponidzia na tle innych obszarów północnej części zapadliska przedkarpackiego, Busko-Zdrój, Uniwersytet Jana Kochanowskiego, Kielce, 2013.

[5] Bąbel M., Tumulusy gipsowe Ponidzia, IV Świętokrzyskie spotkania geologicznogeomorfologiczne nt. Regionalne aspekty funkcjonowania systemów dolinnych, „Jodłowy Dwór” pod Świętym Krzyżem, Akademia Świętokrzyska im. Jana Kochanowskiego, Kielce, pp. 12-15, 2006.

[6] Flis J., Kras gipsowy Niecki Nidziańskiej. Prace Geograficzne, PAN, 1, pp. 7-73, 1954.

[7] Kalicki, T., Krupa, J., Przepióra, P., Kłusakiewicz, E., Kusztal, P., Frączek, M., Górska-Zabielska, M., Nowak, M., Pawłowski, D., Petr, L., Przeździecki, M., Przychodni, A., River valley evolution of Holy Cross Mountains region. In: Kalicki, T., Frączek, M., Przepióra, P. (Ed.), Field Guide of FLAG Biennial Meeting ,Evolution of river valleys in Central Europe”. Kielce-Suchedniów, pp. 48-93, 2016. 